\title{
What is the best material for extracardiac Fontan operation?
}

Toshiharu Shinoka, MD, PhD

From the Department of Surgery, The Ohio State University; and Cardiovascular Tissue Engineering Program, Department of Cardiothoracic Surgery, The Heart Center, Nationwide Children's Hospital, Columbus, Ohio. Disclosures: T.S. has received grant support from Gunze Ltd.

Received for publication Feb 14, 2017; accepted for publication Feb 14, 2017; available ahead of print March 14, 2017.

Address for reprints: Toshiharu Shinoka, MD, PhD, 700 Children's Drive, T2294, Columbus, OH 43205 (E-mail: toshiharu.shinoka@ nationwidechildrens.org).

J Thorac Cardiovasc Surg 2017; 153:1551-2

$0022-5223 / \$ 36.00$

Copyright (C) 2017 by The American Association for Thoracic Surgery

http://dx.doi.org/10.1016/j.jtcvs.2017.02.023

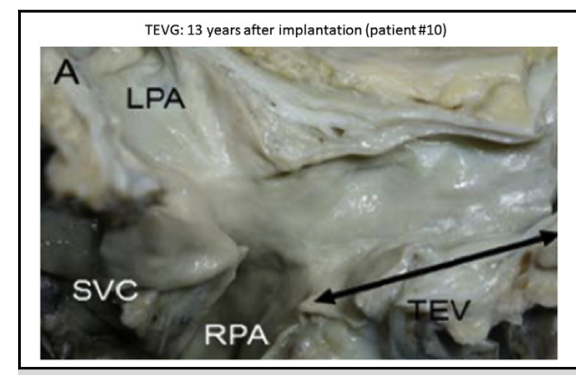

TEVG: 13 years after implantation (patient number 10).

\section{Central Message}

What is the best material for extracardiac Fontan operation?

See Article page 1542.

\section{The patient 22, (Fontan 2/1/2004)}
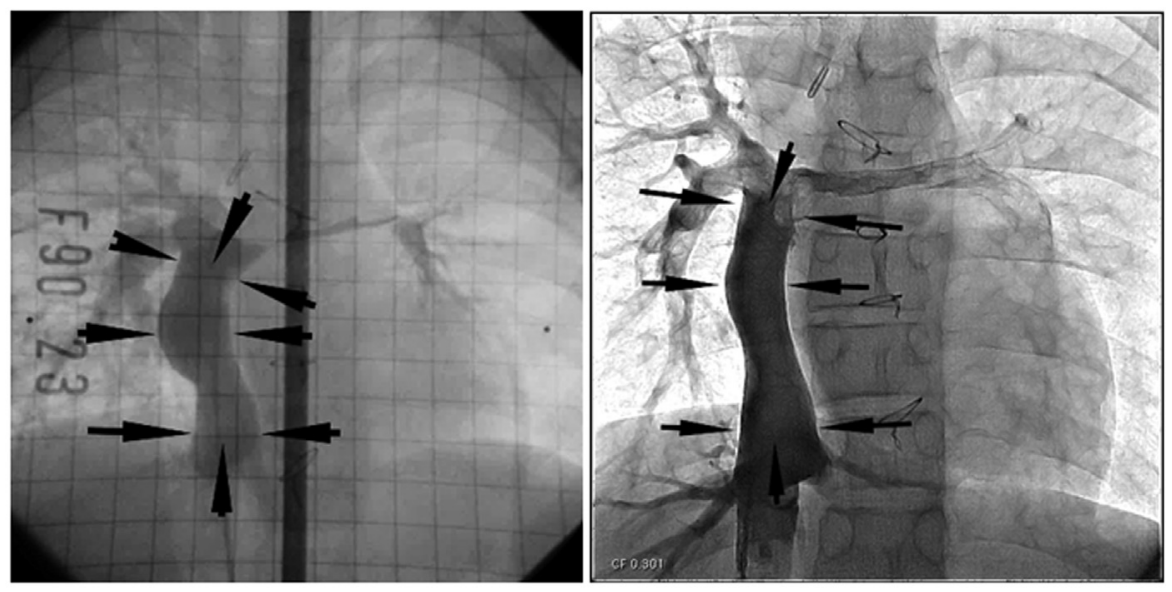

\begin{tabular}{|l|l|c|c|}
\hline & & $4 / 24 / 2006$ & $10 / 7 / 2015$ \\
\hline PA side & Diameter & 15.36 & 15.62 \\
\hline & Area & 219.35 & 207.45 \\
\hline Mid & Diameter & 18.80 & 16.41 \\
\hline & Area & 312.63 & 223.59 \\
\hline \multirow{2}{*}{ IVC side } & Diameter & 17.38 & 20.77 \\
\hline & Area & 239.72 & 320.16 \\
\hline Graft Length & 43.36 & 60.43 \\
\hline
\end{tabular}

FIGURE 1. Two angiographic findings in the same patient demonstrate the growth of TEVG. $P A$, Pulmonary artery; IVC, inferior vena cava. 
nonrandomized single institutional investigations. There also exists variability in postoperative management and follow-up, which leads to significant variability in the reported incidence of many types of postoperative complications. This is especially true for any silent complications (a complication that does not cause symptoms), which can be detected only with appropriate screening. The significance, prevention, and proper management of silent complications remain areas of active debate and investigation. ${ }^{6}$ In the past decades, many surgeons used a variety of materials or techniques for extracardiac Fontan operations, such as Dacron, expanded polytetrafluoroethylene, homograft, autologous pericardium, and xenopericardium. Many articles reported excellent midterm results up to 10 years after using an extracardiac Fontan conduit. However, there is no longerterm follow-up of these materials. We have to remember that our patients have 50 to 60 years ahead. Nobody knows the fate of expanded polytetrafluoroethylene graft 30 to 40 years after implanted in pediatric patients.

In this issue of the Journal, Dr Bockeria and colleagues ${ }^{7}$ from Switzerland have provided human data in their clinical experience of new bioabsorbable vascular grafts in the Fontan circulation. The authors are to be congratulated on the successful clinical outcomes (5 patients followed for 1 year) documented in Russia with novel materials, although I have a small concern about long-lasting foreign body reaction against their slow bioabsorption materials because the histology at 53 weeks after implantation in an animal model still showed that abundant polymer materials remained in the vascular tissue. This reaction might include earlier calcification or intimal thickening of the conduit.

I would briefly like to introduce our 10-year outcomes of a clinical trial of tissue-engineered vascular graft (TEVG) (rapidly bioabsorbable scaffold with bone marrow cell seeding). Between September 2001 and December 2004, 25 patients underwent an extracardiac Fontan using TEVG in Tokyo. ${ }^{8}$ The most updated follow-up data showed that the median patient age at operation was 5.5 years, and the follow-up period was 11.9 and 14.9 years. ${ }^{9}$ No graft-related mortality occurred. There was no evidence of aneurysmal formation, graft rupture, graft infection, or calcification. Seven of 25 patients developed stenosis and underwent at least 1 balloon angioplasty. None of the grafts needed to be surgically revised or replaced. Angiographic assessment in patient 22 shows the growth of graft (Figure 1). On the basis of our animal experimental data, higher dose cell seeding on the graft could reduce the stenosis rate. ${ }^{10}$ Therefore, we are moving forward to the second-generation TEVG trial to reduce the stenosis rate. Figure 2 shows that the later-term (13 years) histologic

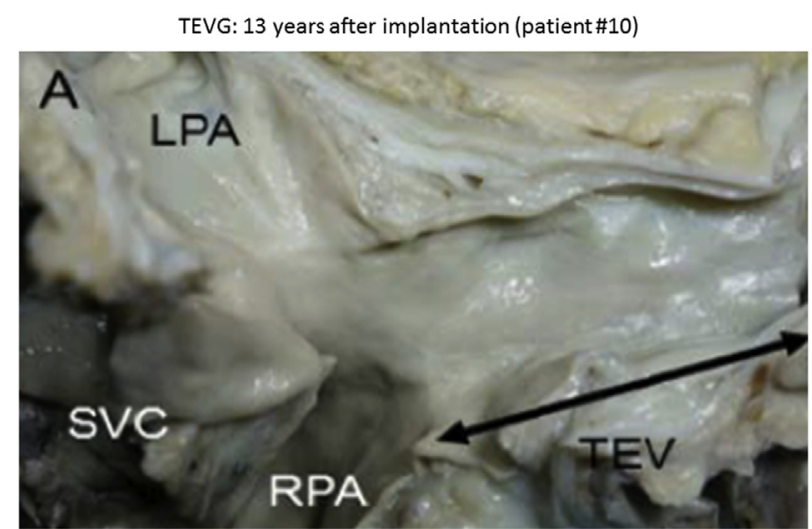

FIGURE 2. Autopsy finding of TEVG 13 years after implantation shows similar structure as the native vein or pulmonary artery. $L P A$, Left pulmonary artery; $S V C$, superior vena cava; $R P A$, right pulmonary artery; $T E V$, tissue-engineered vessel.

characteristics of human TEVG suggest the usefulness of the TEVG strategy in the repair of congenital heart disease. ${ }^{11}$ This technique allows for the development of a biological conduit, including a right ventricle-pulmonary artery conduit with adequate histologic maturation in vivo and better longterm results.

\section{References}

1. Fontan F, Kirklin JW, Fernandez G, Costa F, Naftel DC, Tritto F, et al. Outcome after a "perfect" Fontan operation. Circulation. 1990;81:1520-36.

2. Giannico S, Hammad F, Amodeo A, Michielon G, Drago F, Turchetta A, et al. Clinical outcome of 193 extracardiac Fontan patients: the first 15 years. J Am Coll Cardiol. 2006; 47:2065-73.

3. van Son JA, Reddy M, Hanley FL. Extracardiac modification of the Fontan operation without use of prosthetic material. J Thorac Cardiovasc Surg. 1995;110:1766-8.

4. Adachi I, Yagihara T, Kagisaki K, Hagino I, Ishizaka T, Koh M, et al. Fontan operation with a viable and growing conduit using pedicled autologous pericardial roll: serial changes in conduit geometry. J Thorac Cardiovasc Surg. 2005; 130:1517-22.

5. Lee C, Lee CH, Hwang SW, Lim HG, Kim SJ, Lee JY, et al. Midterm follow-up of the status of Gore-Tex graft after extracardiac conduit Fontan procedure. Eur J Cardiothorac Surg. 2007;31:1008-12.

6. Monagle P, Cochrane A, McCrindle B, Benson L, Williams W, Andrew M. Thromboembolic complications after Fontan procedure - the role of prophylactic anticoagulation. J Thorac Cardiovasc Surg. 1998;115:493-8.

7. Bockeria LA, Svanidze O, Kim A, Shatolov K, Makarenko V, Cox M, et al. Total cavo-pulmonary connection with a new bio-absorbable vascular graft. J Thorac Cardiovasc Surg. 2017;153:1542-50.

8. Shinoka T, Matsumura G, Hibino N, Naito Y, Watanabe M, Konuma T, et al. Midterm clinical results of tissue-engineered vascular autografts seeded with autologous bone marrow cells. J. Thorac. Cardiovasc Surg. 2005;129:1330-8.

9. Hibino N, McGillicuddy E, Matsumura G, Ichihara Y, Naito Y, Breuer C, et al. Late term results of tissue-engineered vascular grafts in humans. J Thorac Cardiovasc Surg. 2010;139:431-6.

10. Lee YU, Mahler N, Best CA, Tara S, Sugiura T, Lee AY, et al. Rational design of an improved tissue-engineered vascular graft: determining the optimal cell dose and incubation time. Regen Med. 2016;11:159-67.

11. Matsumura G, Shinoka T. First report of histological evaluation of human tissueengineered vasculature. Biotechnol Biomater. 2016;5:200. 